\title{
Piscis non grata in the Mediterranean Sea: Pterois miles (Bennett, 1828)
}

\section{Akdeniz'de istenmeyen balık: Pterois miles (Bennett, 1828)}

\section{Sercan Yapıci ${ }^{1}$}

'Muğla Sıtkı Koçman University, Faculty of Fisheries, 48000, Kötekli, Muğla, Turkey, (iD https://orcid.org/0000-0003-2288-5084 sercanyapici@mu.edu.tr

\section{How to cite this paper:}

Yapıcı, S. (2018). Piscis non grata in the Mediterranean Sea: Pterois miles (Bennett, 1828). Ege Journal of Fisheries and Aquatic Sciences, 35(4), 467-474. DOI:10.12714/egejfas.2018.35.4.13

\begin{abstract}
Pterois miles is currently considered a marine invader, especially in the western Atlantic where the species has been introduced in the middle of 1980's, at about the same time the species first appeared in the eastern Mediterranean. West Atlantic experience and the relevant literature told us that 'a P. miles invasion has begun in the Mediterranean'. Here, the research is presented providing important integrating data from the invasion by the same species in the Atlantic, the current status and historical distribution of $P$. miles in the Mediterranean with a northernmost occurrence of the species from the Aegean Sea (off Didim coast, Turkey).
\end{abstract}

Keywords: Lionfish, Pterois miles, biological invasion, Mediterranean Sea, range expansion

Öz: Özellikle 1980'lerin ortasında batı Atlantik'e giriş yapan, denizel bir istilacı tür olarak kabul edilen Pterois miles, benzer zaman diliminde ilk kez doğu Akdeniz'de ortaya çıkmıştır. Batı Atlantik deneyimi ve ilgili literatür bize "Akdeniz'de P. miles saldırııının başladığını" söylemektedir. Bu çalışma Akdeniz'deki P. miles'in bugünkü durumu, tarihsel dağılımı ile Ege Denizi'ndeki en kuzey dağılımı hakkında (Didim sahili, Türkiye) önemli entegre veriler sunmaktadır.

Anahtar kelimeler: Aslan balığı, Pterois miles, biyolojik istila, Akdeniz, dağılım genişlemesi 


\section{INTRODUCTION}

Now, we are witnessing a rapid invasion of lionfish, Pterois miles (Bennett, 1828), in the Mediterranean from a single specimen in 1991 to several sightings between 2014 and 2016 in the eastern Mediterranean Sea (Bilge et al., 2016). This increase is very similar to the pattern of invasion recorded for lionfishes ( $P$. volitans/miles) in western Atlantic (Albins and Hixon, 2013). Judging from the recent increase in $P$. miles in the eastern Mediterranean Sea (Filiz et al., 2017), we suspect that a rapid expansion throughout the Mediterranean Sea. Indeed, in both its native and introduced ranges, lionfishes thrive in warm waters ideally between 20 and $30^{\circ} \mathrm{C}$ (Turingan and Sloan, 2016), so, given the predicted increases in water temperature expected in the Mediterranean, the ability for long distance dispersal of planktonic larvae, and the generality of habitat use it is expected that the invaded area will continue to expand. All the recent findings of $P$. miles may be an indication of a new wave of arrivals of the species in the eastern Mediterranean, raising justifiable concerns of a possible onset of a new invasion mentioned by Bariche et al. (2013) in the Mediterranean Sea.

Here, we presented a review providing important integrating data from the invasion by $P$. miles in the Atlantic, the current status and historical distribution of $P$. miles in the eastern Mediterranean with a northernmost occurrence of the species from the Aegean Sea (off Didim coast, Turkey).

\section{MATERIAL AND METHODS}

On 05 April 2017, one specimen of $P$. miles (Figure 1) was observed and photographed by a SCUBA diver from off Didim coast $\left(37^{\circ} 20^{\prime} \mathrm{N}, 27^{\circ} 14^{\prime} \mathrm{E}\right)$ on a rocky bottom at depths of $18 \mathrm{~m}$. The water temperature was $14.3^{\circ} \mathrm{C}$. The specimen was identified based on the description provided by Golani et al. (2006) using high quality photos.

Figure 1. Underwater view of new recorded $P$. miles specimen in the Aegean Sea

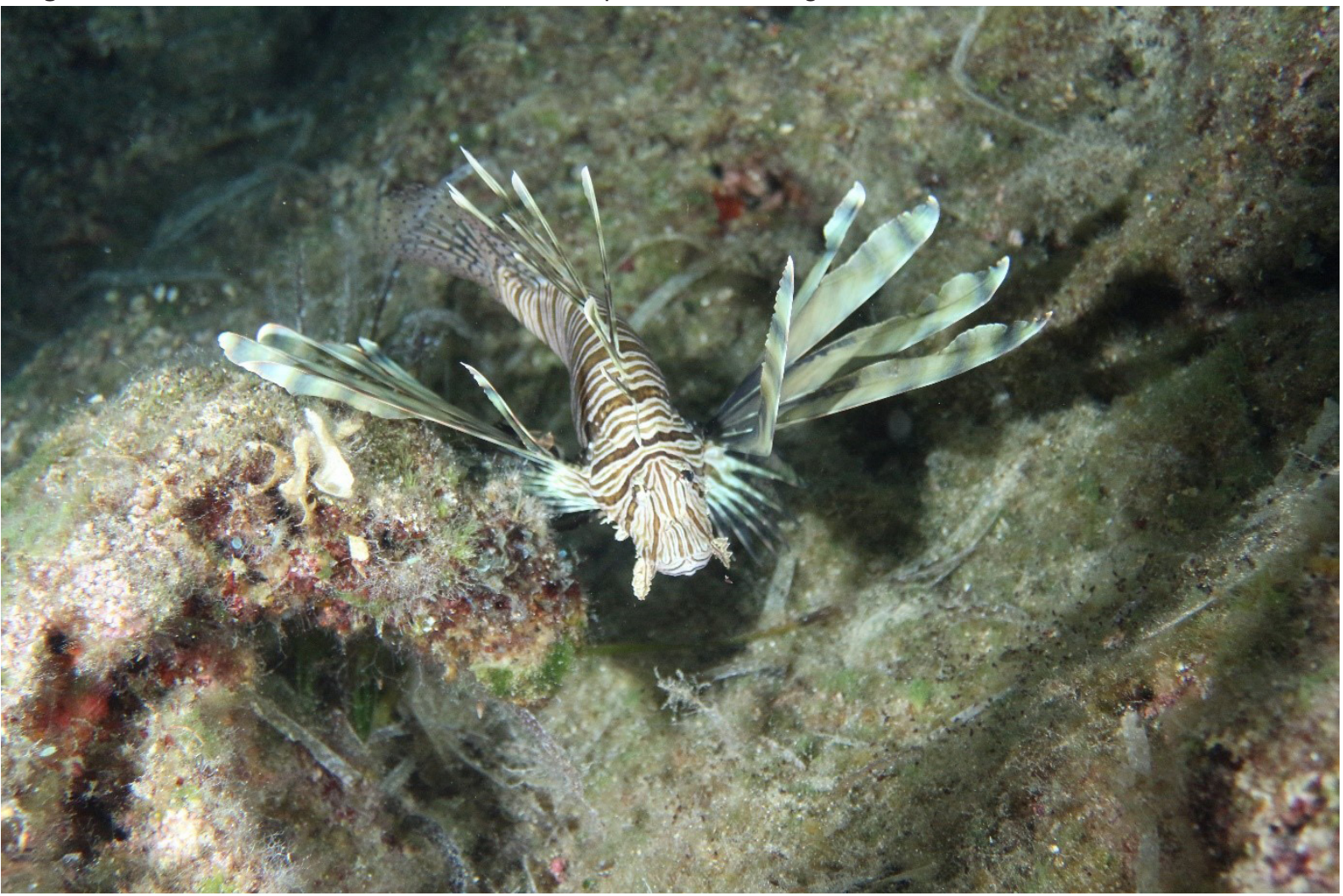

Peer-viewed publications were priority sources, so a total of 26 reliable literatures were compared to obtain all available information on biogeographical (locality, coordinates) and historical traits (sampling date), and biological (sample size, catching/observation method) and ecological characteristics (habitat type, depth, temperature) of $P$. miles for the Mediterranean.

\section{RESULTS}

Unique features of specimen were clearly visible and noticeable: Long and venomous dorsal spines longer than body. Body is reddish to tan and numerous thin dark bars on body and head vertically; visible small spots in the median fins. 
The chronological order of the $P$. miles sightings, which accounts for the period July 1991 to April 2017, showed a progressive expansion of the $P$. miles in the eastern and western Mediterranean (Table 1 and Figure 2). To our best knowledge, no published records of the $P$. miles are available for the Mediterranean coasts of Egypt and Libya (Froese and Pauly, 2018), but recently from Italy in the western Mediterranean by Azzurro et al. (2017). A total of 26 reliable records of $P$. miles were reported in the Mediterranean Sea (Table 1). The species was collected by a variety of different fishing gears along the Mediterranean coasts like bottom trawl, trammel and gill nets, wire trap, spearfishing and collected net or via scuba diving from $2 \mathrm{~m}$ (Crocetta et al., 2015; Jimenez et al., 2016) to 110 m (Yağlığlu and Ayaş, 2016), mostly ranged 2-35 $\mathrm{m}$, since the data were collected primarily by SCUBA divers and, therefore, is limited in its application to relatively shallow depths.

Figure 2. The distribution map of scientific reports of $P$. miles occurrences in the Mediterranean Sea ('Golani and Sonin (1992), ${ }^{2,3}$ Bariche et al. (2013), ${ }^{4}$ Turan et al. (2014), ${ }^{5-7}$ Crocetta et al. (2015), ${ }^{8}$ Iglésias and Frotté (2015), ${ }^{9}$ Oray et al. (2015), ${ }^{10}$ Turan and Öztürk (2015), ${ }^{11,12 B i l g e ~ e t ~ a l . ~(2016), ~}{ }^{13-18}$ Daillianis et al. (2016), ${ }^{19} \mathrm{Jimenez}$ et al. (2016), ${ }^{20-22}$ Mytilineou et al. (2016), ${ }^{23}$ Yağlıoğlu and Ayaş (2016), ${ }^{24}$ Azzurro et al. (2017), ${ }^{25}$ Özgür Özbek et al. (2017) and ${ }^{26}$ Present study. For further details, see Table 1).

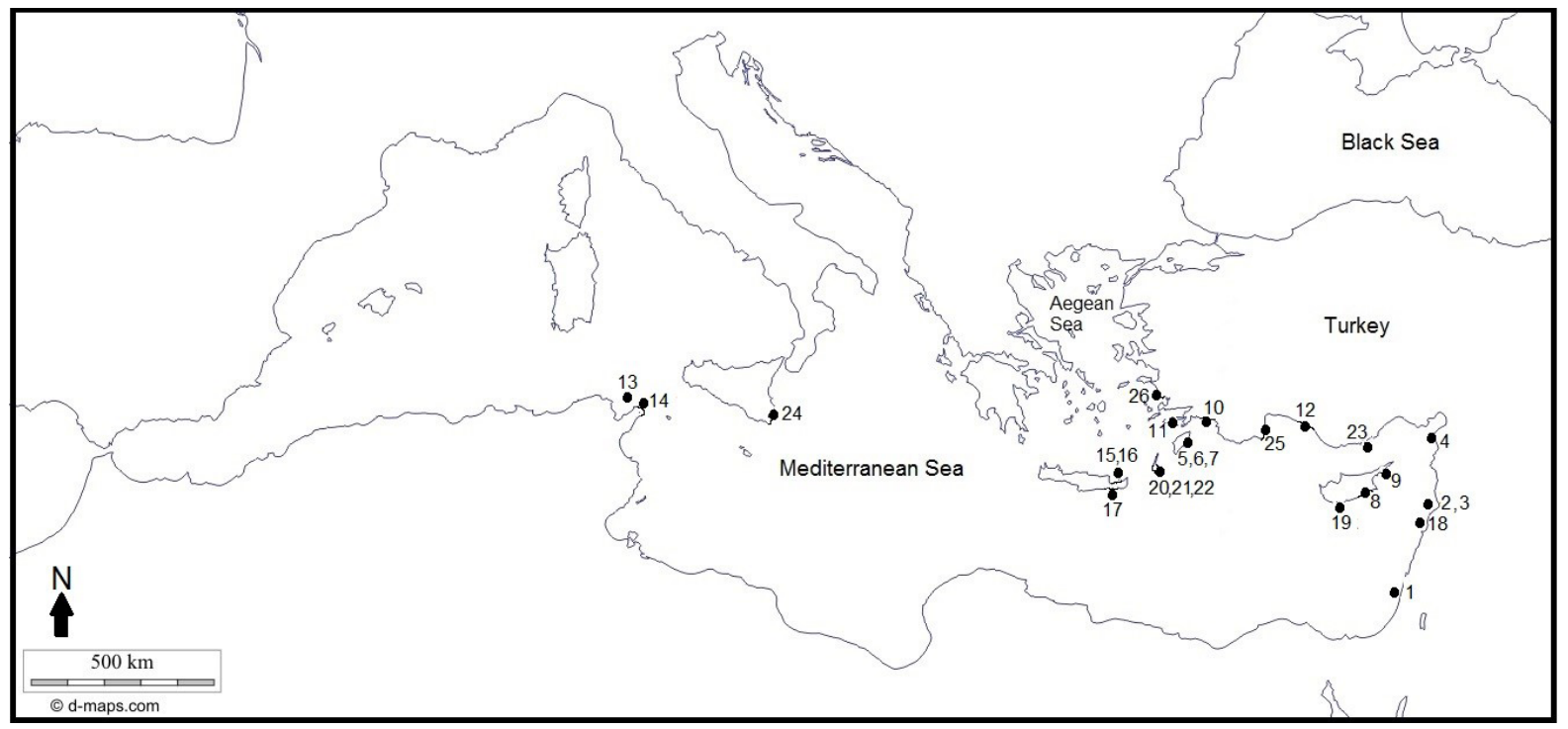




\begin{tabular}{|c|c|c|c|c|c|c|c|c|c|c|c|c|c|c|c|c|c|c|c|c|c|c|c|c|}
\hline & 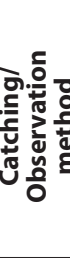 & & 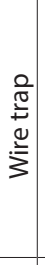 & & ' & $\stackrel{\text { : }}{\text { : }}$ & $\overbrace{0}^{g}$ & : & $\overrightarrow{\underline{z}}$ & 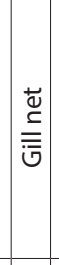 & 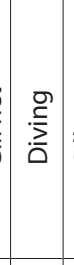 & $\mid \begin{array}{l}\overrightarrow{\mathrm{g}} \\
\underline{\overline{\mathbf{v}}}\end{array}$ & 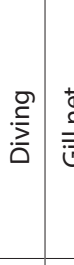 & 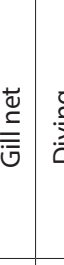 & 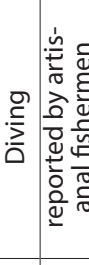 & 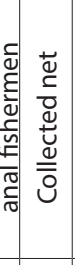 & 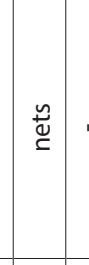 & 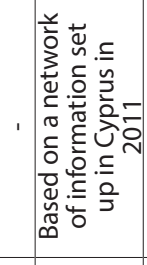 & S. & 旁 & 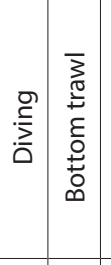 & 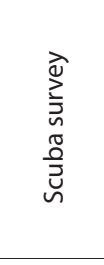 & 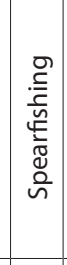 & 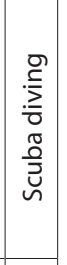 \\
\hline & ปัँ & $\begin{array}{l}\bar{\sigma} \\
\alpha \\
\vdots \\
\hat{0} \\
\infty \\
\infty \\
\end{array}$ & 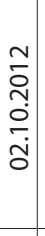 & 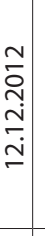 & 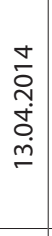 & 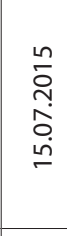 & 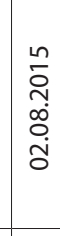 & 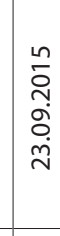 & 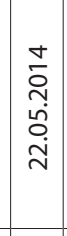 & 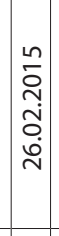 & 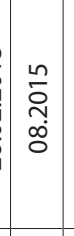 & 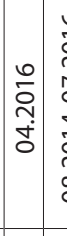 & 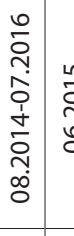 & 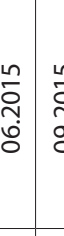 & 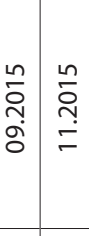 & & 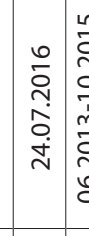 & 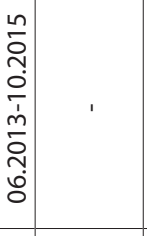 & $\mid$\begin{tabular}{l|}
0 \\
0 \\
0 \\
0 \\
$\infty$ \\
$\infty$ \\
$\infty$ \\
$\infty$
\end{tabular} & 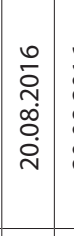 & 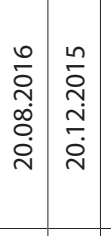 & 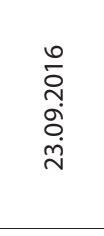 & 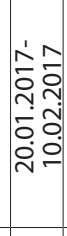 & 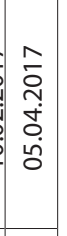 \\
\hline & $\frac{\bar{a}}{\square}$ & 1 & . & & , & 1 & 1 & ' & . & & ' & & $\begin{array}{l}0 \\
\text { ஸे } \\
\text { Oें } \\
\text { ¿े }\end{array}$ & & ' & & 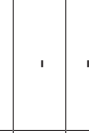 & ' & ' & ' & ' & ' & 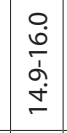 & $\stackrel{m}{\stackrel{m}{\ddagger}}$ \\
\hline & 竎 $\bar{g}$ & $\stackrel{n}{m}$ & $\stackrel{\circ}{m}$ & & $\stackrel{\Perp}{\sim}$ & 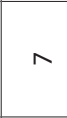 & ' & $N$ & 운 & P & $=$ & $\circ$ & $\begin{array}{c}\stackrel{\sim}{\sim} \\
\dot{q}\end{array}$ & in & ' & $m$ & 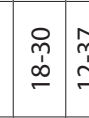 & 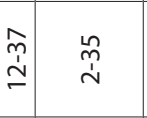 & $\approx$ & 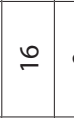 & 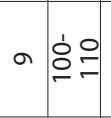 & $\stackrel{n}{m}$ & $\stackrel{n}{\frac{n}{c}}$ & $\stackrel{\infty}{-}$ \\
\hline & 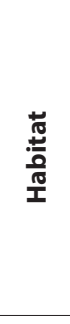 & & 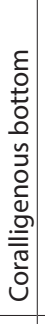 & 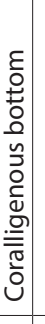 & & 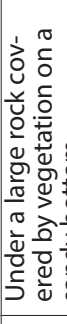 & & & & 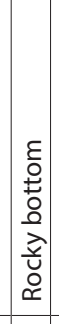 & 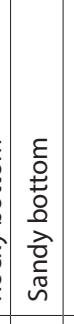 & & 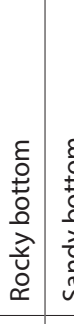 & 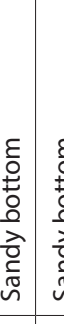 & 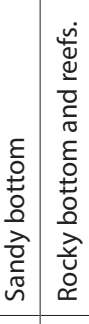 & 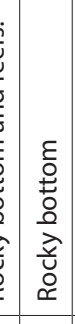 & 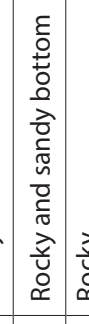 & 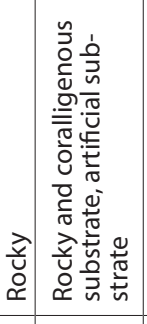 & 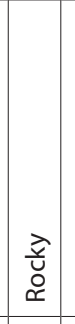 & \begin{tabular}{|l|}
$\vec{s}$ \\
0 \\
0 \\
$\propto$
\end{tabular} & . & 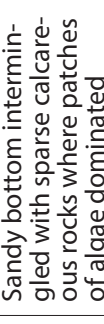 & 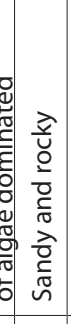 & 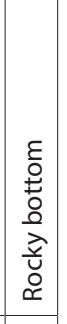 \\
\hline & 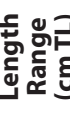 & & & ڤें & $\stackrel{\stackrel{\bullet}{\sim}}{\stackrel{\sim}{*}}$ & , & ' & ' & 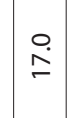 & $\stackrel{m}{m}$ & 1 & ' & . & ָ̊. & ' & 品 & $\stackrel{\circ}{\circ}$ & 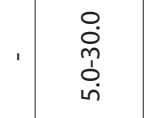 & 으 & i & 으 & 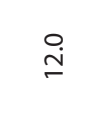 & $\begin{array}{l}m \\
\stackrel{2}{2} \\
i \\
\infty \\
\infty\end{array}$ & ' \\
\hline & $=$ & - & - & - & - & - & - & - & - & - & - & $-:$ & $\stackrel{m}{ }$. &.- & $-N$ & - & -7 & 8 & - & - & -- & - & $\infty$ & - \\
\hline & 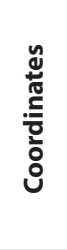 & & 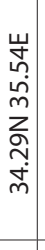 & | & & 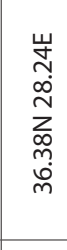 & 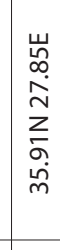 & 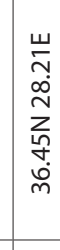 & . & & & 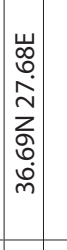 & & 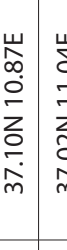 & 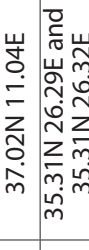 & 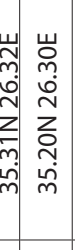 & 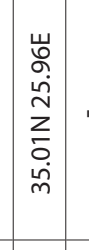 & 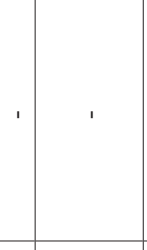 & 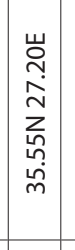 & 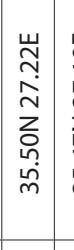 & 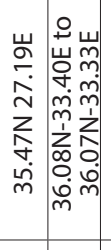 & 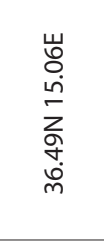 & & 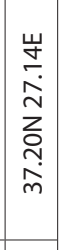 \\
\hline & 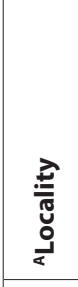 & 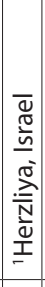 & 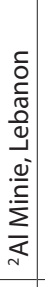 & 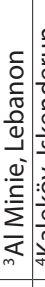 & & 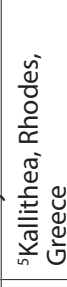 & 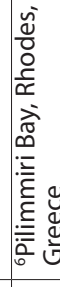 & 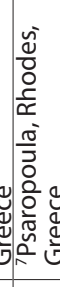 & 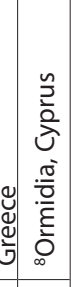 & 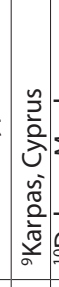 & 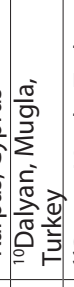 & 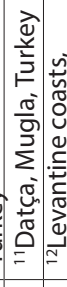 & 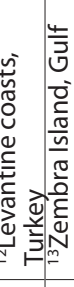 & 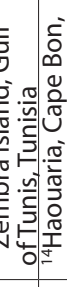 & 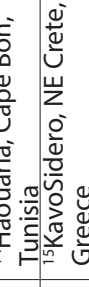 & 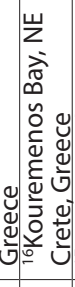 & 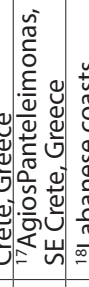 & 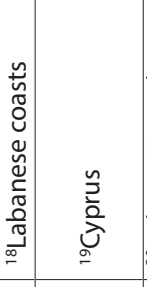 & 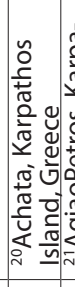 & 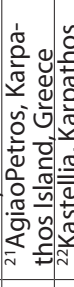 & 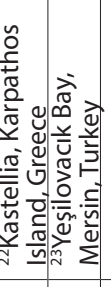 & 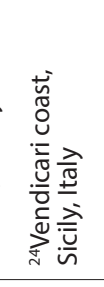 & & 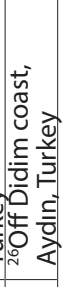 \\
\hline & ڤัّ & 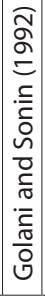 & 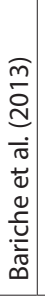 & & & 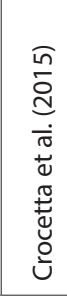 & & & 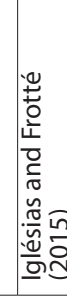 & 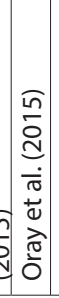 & 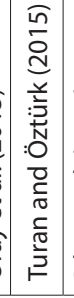 & 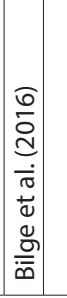 & & 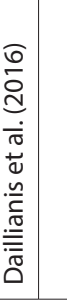 & 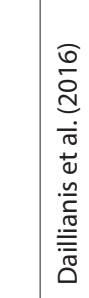 & & & 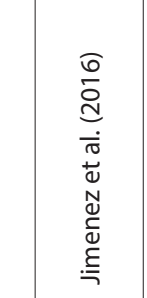 & 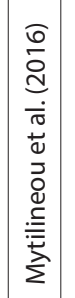 & & 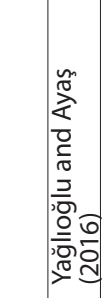 & 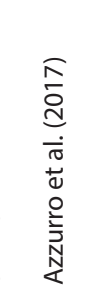 & 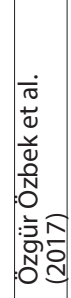 & 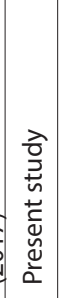 \\
\hline
\end{tabular}


The species found in a variety of habitats. Recorded numbers ranged from one (most records) to 90 (Jimenez et al., 2016) individuals, lengths ranged from $5 \mathrm{~cm}$ (Jimenez et al., 2016) to $37.3 \mathrm{~cm}$ (Oray et al., 2015). The most west, east, north, and south records of the species were in Sicily (Italy), Al Minie (Lebanon), Didim coast (Turkey), and Haifa (Israel), respectively (Table 1). Most of the records were obtained in summer, the seawater temperatures were ranged from $14.3^{\circ} \mathrm{C}$ in April 2017 (present study) to $29.0^{\circ} \mathrm{C}$ in August 2015 (Bilge et al., 2016).

\section{DISCUSSION}

The lionfishes' introduction provides a reminder of how rapidly a non-native species can become established and potentially compete with native fishes for resources (Morris et al., 2008). The lionfishes' invasion in the western Atlantic represented one of the most rapid and extensively documented marine fish invasion in history. After the lionfishes have colonized large areas of the western Atlantic, resulting in an immense ecological damage, Albins and Hixon (2013) commented on the situation as: "with an eye on the future, we describe a possible worst case scenario". P. miles has been recorded as a first time on the western Atlantic coast in 1985 (Schofield, 2009), during a dark 15 years, no sightings were mentioned until 2000. Thereafter, it was again started to report, increasingly, became fully established throughout the southeast United States (US) and the Caribbean Sea, extending to South America and much of the Gulf of Mexico (Schofield, 2009 and references therein; Kletou et al., 2016), becoming the first non-native marine fish to establish self-sustaining populations in these region (Ruttenberg et al., 2012). The most likely vectors for the introduction were releases or escapes either intentional or accidental from marine aquaria (Albins and Hixon, 2011; Kletou et al., 2016), since the lionfishes are a popular ornamental aquarium fish that have been imported into the U.S.A in large numbers (Morris and Akins, 2009). But, still, the exact cause of introduction has not been determined (NMFS, 2015). Betancur-R et al. (2011) showed that the invasive population of lionfishes in the western Atlantic has a significantly lower genetic diversity than populations from their native range, which is associated with a strong founder effect, and is thought to originate a relatively small number of founder population in the southeast US. Similarly, in the Mediterranean Sea, a single specimen of $P$. miles was recorded from the Levantine coast in 1991 (Golani and Sonin, 1992). During the twenty-one years' period, no observation was happened in the Mediterranean, even, just before Johnston and Purkis (2014) claimed that a natural invasion of the Mediterranean Sea by $P$. miles was unlikely, two $P$. miles individuals were captured separately in the northern part of Lebanon (Bariche et al., 2013). Then, additional sightings were reported one after another along the coasts of Cyprus (Iglésias and Frotté, 2015; Oray et al., 2015; Jimenez et al., 2016;
Kletou et al., 2016), Turkey (Turan et al., 2014; Turan and Öztürk, 2015; Bilge et al., 2016; Yağlığlu and Ayaş, 2016), Rhodes (Crocetta et al., 2015), Tunisia (Dailianis et al., 2016), and rarely from western Mediterranean (Azzurro et al., 2017). The time passed between the first and the second records of this species both in Atlantic and Mediterranean seems lengthy. Azzurro et al. (2016) explained this phenomenon as a failed introduction: "Considering the conspicuous appearance of P. miles, and its relatively ease in recognition, the lack of observations until 2012 is unlikely "a detection lag" and the 1991 record (Golani and Sonin, 1992) can be considered as evidence of a failed introduction". While marine scientists in the Mediterranean region were trying to understand the introduction vectors (aquarium release, transport by ship ballast water, dispersal event from an Atlantic source or passage through the Suez Canal as Lessepsian immigrant) of the invading population in the Mediterranean Sea, recently, Bariche et al. (2017) showed that the very first individuals establishing populations in the Mediterranean Sea displayed haplotypes that nest within the large genetic diversity of Red Sea individuals, thus indicating an invasion via the Suez Canal, concluded that the Mediterranean invasion was the result of a movement of individuals from the Red Sea. While a model predicted that a natural invasion of the Mediterranean Sea by $P$. miles was unlikely to be successful (Johnston and Purkis, 2014) since the oceanographic conditions in the Mediterranean were unfavourable for the dispersion of $P$. miles larvae, and Mediterranean marine scientists discussed whether the species could invade this region like it has in the western Atlantic, recently Kletou et al. (2016) warned us that "A lionfish (Pterois miles) invasion has begun in the Mediterranean Sea". Although, Azzurro and Bariche (2017) stated that current abundances of $P$. miles are still below the threshold of a "true invasion", recently, in order to see and compare the invasiveness of the Lessepsian fishes, a threshold was calculated as 18.5 using AS-ISK (Aquatic Species Invasiveness Screening Kit; available at https://www.cefas.co.uk/ nns/tools/) analysis (Bilge et al., 2017). Considering the high Basic Risk Assessment (BRA) score 45.5 for $P$. miles (Bilge et al., 2017) now, it can be considering that $P$. miles is possibly the most invasive marine fish in the Mediterranean and possesses a very high risk to biodiversity. In contrast to Johnston and Purkis (2014)'s assumption, it's obvious that, now, P. miles may have already been found a favourable oceanographic conditions in the Mediterranean. Supporting this idea, Poursanidis (2015) provided an insight to the potential expansion of the $P$. miles in the Mediterranean Sea and the identification of the suitable areas for it to establish. On the other hand, in contrast to limited gene pool in the Atlantic population (Betancur-R et al., 2011), rich genetic diversity in the Mediterranean population (Bariche et al., 2017) may support invading success and also have distribute in wider habitats and live at lower 
temperatures in the Mediterranean Sea. Furthermore, $\mathrm{CO}_{2}$ emissions which are warming the Mediterranean Sea and the construction of a deeper and wider Suez Canal are expected to increase invasion rates (Galil et al., 2015; Hall-Spencer and Allen, 2015).

$P$. miles has been considered highly temperature dependent (Dabruzzi et al., 2017), according to Kimball et al. (2004) P. miles unable to survive below $10{ }^{\circ} \mathrm{C}$. It was mentioned some temperature limitations for the Lessepsian fishes in the Mediterranean. For example, while Corsini and Stamatellos (1998) suggested that water temperatures around $12{ }^{\circ} \mathrm{C}$ may constitutes a fatal limit for Pteragogus pelycus, controversially, it was reported Stephanolepis diaspros can be survive at $11.5^{\circ} \mathrm{C}$ (Béjaoui et al., 2008) and $12^{\circ} \mathrm{C}$ (Corsini-Foka et al., 2010). Recently, Özgür Özbek et al. (2017) noted that the P. miles continued feeding in low winter temperature $\left(14.9^{\circ} \mathrm{C}\right)$. This low winter inshore temperature is below the temperature threshold $\left(16.1^{\circ} \mathrm{C}\right)$ at which experimental lab studies have suggested the lionfish stops feeding (Kimball et al., 2004). The more widespread colonisation of the Mediterranean and Aegean region by $P$. miles seems no temperature dependent. In a way that support it, Bilecenoğlu (2016) tested six environmental variables on Lessepsian fish assemblage by the multivariate analysis, and he found that only a single species (Nemipterus randalli) had a positive correlation with water temperature. Anyway, further studies in the Mediterranean should focus on the interaction between lionfishes and seasonal watertemperature variation in order to better understand whether temperature has a more significant role at the invasion range limit.

The data were presented in Table 1 collected primarily by SCUBA divers and, therefore, is limited in relatively shallow depths. According to literature, P. miles is naturally distributed in the tropical waters of the Indian Ocean, Persian Gulf and the Red Sea from South Africa to Indonesia up to 60 or 65 m (Froese and Pauly, 2017). But there is evidence from the Atlantic literature that lionfishes (Pterois spp.) may found on mesophotic zone. For example, lionfishes reported from $100 \mathrm{~m}$ off North Carolina (Meister et al., 2005), over $100 \mathrm{~m}$ in the Bahamas (Bejarano et al., 2014), $112 \mathrm{~m}$ in northwestern Gulf of Mexico (Nuttall et al., 2014), $120 \mathrm{~m}$ in Honduras (Schofield, 2010), $126 \mathrm{~m}$ on Puerto Rico coast and $167 \mathrm{~m}$ on Conrad Seamount (Quattrini et al., 2017), $247 \mathrm{~m}$ in Çuraçao (Tornabene and Baldwin, 2017), $240 \mathrm{~m}$ in Roatan and $304 \mathrm{~m}$ in Bermuda (Gress et al., 2017). On the other hand, Johnston and Purkis (2011) suggested that lionfish may extend their maximum depth to $610 \mathrm{~m}$. It seemed the deeper waters can be used as a potential refuge for invasive lionfish as indicated by Andradi-Brown et al. (2017). But these studies' data included two species ( $P$. volitans and $P$. miles), and since no separated data presented, we cannot be sure which species really occur deeper waters, one we could accept that $P$. volitans and $P$. miles are considered to be ecologically similar as they have non-overlapping native ranges it would be worth acknowledging they are likely to be deeper. Recently, a more certain evidence, regarding only P. miles, was provided by Yağlıoğlu and Ayaş (2016) from the Mediterranean. They reported that, a P. miles was captured by commercial bottom trawl fishery at a depth of 100 to 110 m from Yesilovacık Bay, Mersin, Turkey (NorthEastern Mediterranean). There are very few observations available for depths beyond recreational SCUBA diving limits in the Mediterranean. West Atlantic examples showed that additional sampling beyond traditional diver surveys is needed to gain a more complete understanding of the $P$. miles invasion process and the threats it poses to different habitat and ecosystem types. Previous studies have documented that $P$. miles invasions can begin in shallow habitats, but progressing to deeper habitats with time as indicated before by Claydon et al. (2012) and Andradi-Brown et al. (2017), so we may be face a deeper invasion needed to detailed study in the Mediterranean.

Although clear signs of numerical increase emerged, and raising concerns for an incipient $P$. miles invasion (Dailianis et al., 2016; Kletou et al., 2016; Azzurro and Bariche, 2017), little was known regarding the its biology and ecology in the Mediterranean. Considering literature including experimental, applied studies in western Atlantic and applied risk screening tool for the Mediterranean (Filiz et al., 2017), it is known that it has many biological abilities expected of a successful invader, such as high climate match, tolerance of a wide range of environmental conditions, flexibility in utilising food resources, high fecundity, small size at maturity, high reproductive effort (Azzurro et al., 2017; Filiz et al., 2017) which can be obtained certain critical data such as abundance, dietary habits, predators, and reproduction of $P$. miles are scarce for the Mediterranean.

In spite of all the negativities of the Mediterranean scientists and data obtained from literature, the diving schools seem very happy the occurrence of $P$. miles in the coastal waters in Antalya and Muğla province since the $P$. miles is an attractive marine fish for the divers. A similar point of view was also reported from Cyprus by Jimenez et al. (2017).

The northward occurrence of $P$. miles in the present study, as well as previous reports, may be evidence its accelerating expansion through the Mediterranean Sea and adjacent seas. In conclusion, status of $P$. miles in the Mediterranean and adjacent seas should be monitored closely via formal and citizen sciences. The recent and rapid expansion of the $P$. miles in the Mediterranean is therefore alarming and requires the immediate action of all concerned stakeholders in the area (Bariche et al., 2017). Finally, it is vital that the ecology and distribution of the invasive species is fully understood to design the most effective form of control (Andradi-Brown et al., 2017).

\section{ACKNOWLEDGEMENTS}

Author would like to thank Prof. Dr. Halit FiLiz and Assoc. Prof. Dr. Gökçen BILGE for valuable and constructive contributions. 


\section{REFERENCES}

Albins, M.A. \& Hixon, M.A. (2011). Worst case scenario: Potential long-term effects of invasive predatory lionfish (Pterois volitans) on Atlantic and Caribbean coral-reef communities. Environmental Biology of Fishes, 96(10-11), 1151 1157. DOI: 10.1007/s10641-011-9795-1

Andradi-Brown, D.A., Vermeij, M.J., Slattery, M., Lesser, M. Bejarano, I., Appeldoorn, R., ... \& Exton, D. A. (2016). Largescale invasion of western Atlantic mesophotic reefs by lionfish potentially undermines culling-based management. Biological Invasions, 19(3), 939-954. DOI: 10.1007/s10530-016-1358-0

Azzurro, E. \& Bariche, M. (2017). Local knowledge and awareness on the incipient lionfish invasion in the eastern Mediterranean Sea. Marine and Freshwater Research, 68(10), 1950. DOI: $10.1071 / \mathrm{mf} 16358$

Azzurro, E., Maynou, F., Belmaker, J., Golani, D. \& Crooks, J. A. (2016). Lag times in Lessepsian fish invasion. Biological Invasions, 18(10), 2761-2772. DOI: 10.1007/s10530-016-1184-4

Azzurro, E., Stancanelli, B., Di Martino, V. \& Bariche, M. (2017). Range expansion of the common lionfish Pterois miles (Bennett, 1828) in the Mediterranean Sea: an unwanted new guest for Italian waters. Biolnvasions Records, 6(2), 95-98. DOI: 10.3391/bir.2017.6.2.01

Bejarano, I., Appeldoorn, R.S. \& Nemeth, M. (2014). Fishes associated with mesophotic coral ecosystems in La Parguera, Puerto Rico. Coral Reefs, 33(2), 313-328. DOI: $10.1007 / \mathrm{s} 00338-014-1125-6$

Bariche, M., Torres, M., \& Azzurro, E. (2013). The Presence of the invasive Lionfish Pterois miles in the Mediterranean Sea. Mediterranean Marine Science, 14(2), 292. DOI: $10.12681 / \mathrm{mms} .428$

Bariche, M., Kleitou, P., Kalogirou, S. \& Bernardi, G. (2017). Genetics reveal the identity and origin of the lionfish invasion in the Mediterranean Sea. Scientific Reports, 7(1). DOI: $10.1038 / s 41598-017-07326-1$

Béjaoui, B., Harzallah, A., Moussa, M., Chapelle, A. \& Solidoro, C. (2008). Analysis of hydrobiological pattern in the Bizerte lagoon (Tunisia). Estuarine, Coastal and Shelf Science, 80(1), 121-129. DOI: 10.1016/j.ecss.2008.07.011

Betancur-R., R., Hines, A., Acero P., A., Ortí, G., Wilbur, A. E. \& Freshwater, D. W. (2011). Reconstructing the lionfish invasion: insights into Greater Caribbean biogeography. Journal of Biogeography, 38(7), 1281-1293. DOI: $10.1111 /$ j.1365-2699.2011.02496.x

Bilecenoğlu, M. (2016). Demersal Lessepsian fish assemblage structure in the northern Levant and Aegean Seas. Journal of the Black Sea / Mediterranean Environment, 22(1), 46-59.

Bilge, G., Filiz, H., Yapıcı, S. \& Gülşahin, A. (2016). On the occurrence of the devil firefish Pterois miles (Scorpaenidae), from the southern Aegean Sea with an elaborate occurrences in the Mediterranean coast of Turkey. HydroMediT 2016, 2nd International Congress on Applied Ichthyology and Aquatic Environment, Messolonghi, Greece.

Bilge, G., Filiz, H., Yapıcı, S. \& Tarkan, A.S. (2017). How can be decided the true invasion potential: Applying Aquatic Species Invasiveness Screening Kit (AS-ISK) for Lessepsian fishes. II. Workshop on Invasive Species: Global Meeting on Invasion Ecology Proceedings, Bodrum, Turkey.

Claydon, J., Calosso, M. \& Traiger, S. (2012). Progression of invasive lionfish in seagrass, mangrove and reef habitats. Marine Ecology Progress Series, 448, 119-129. DOI: 10.3354/meps09534

Corsini, M. \& Stamatellos, S. (1998). Information collected at the Hydrobiological Station of Rhodes (Greece) on Lessepsian migrant fshes. Proceedings of the 16th European Union of Aquarium Curators Symposium, Barcelona.

Corsini-Foka, M. Pancucci-Papadopoulou, M.A \& Kalogirou, S. (2010). Is the Lessepsian Province in expansion? The Aegean Sea experience. Report of the Sub-Regional Technical meeting on the Lessepsian migration and its impact on Eastern Mediterranean fishery. GCP/INT/041/EC-GRE-ITA/TD-04, FAO EastMed Working Document.

Crocetta, F., Agius, D., Balistreri, P., Bariche, M., Bayhan, Y. K., ... \& Zenetos, A. (2015). New Mediterranean Biodiversity Records (October 2015). Mediterranean Marine Science, (3), 682-702. DOI: $10.12681 / \mathrm{mms} .1477$

Dabruzzi, T., Bennett, W. \& Fangue, N. (2017). Thermal ecology of red lionfish Pterois volitans from southeast Sulawesi, Indonesia, with comparisons to other Scorpaenidae. Aquatic Biology, 26, 1-14. DOI: 10.3354/ab00668

Dailianis, T., Akyol, O., Babalı, N., Bariche, M., Crocetta, F., ... \& Trkov, D. (2016). New Mediterranean Biodiversity Records (July 2016). Mediterranean Marine Science, 17(2), 608-626. DOI: $10.12681 / \mathrm{mms} .1734$

Filiz, H., Tarkan, A.S., Bilge, G. \& Yapıcı, S. (2017). Assessment of invasiveness potential of Pterois miles by the Aquatic Species Invasiveness Screening Kit. Journal of the Black Sea / Mediterranean Environment, 23(1), 17-37.

Froese, R. \& Pauly, D. (2018). FishBase. World Wide Web electronic publication. www.fishbase.org, version (02/2017)

Galil, B. S., Boero, F., Campbell, M. L., Carlton, J. T., Cook, E., Fraschetti, S., ... \& Ruiz, G. M. (2014). 'Double trouble': the expansion of the Suez Canal and marine bioinvasions in the Mediterranean Sea. Biological Invasions, 17(4), 973-976. DOI: $10.1007 / s 10530-014-0778-y$

Golani, D. \& Sonin, O. (1992). New records of the Red Sea fishes, Pterois miles (Scorpaenidae) and Pteragogus pelycus (Labridae) from the eastern Mediterranean Sea. Japanese Journal of Ichthyology, 39(2), 167-169.

Golani, D., Özturk, B. \& Başusta, N. (2006). Fishes of the eastern Mediterranean. Turkish Marine Research Foundation, Istanbul, Turkey.

Gress, E., Andradi-Brown, D. A., Woodall, L., Schofield, P. J., Stanley, K. \& Rogers, A. D. (2017). Lionfish (Pterois spp.) invade the upperbathyal zone in the western Atlantic. PeerJ, 5, e3683. DOI: $10.7717 /$ peerj.3683

Hall-Spencer, J. M. \& Allen, R. (2015). The impact of ocean acidification on 'nuisance' species. Research and Reports in Biodiversity Studies, 4, 33-46.

Iglésias, S. \& Frotté, L. (2015). Alien marine fishes in Cyprus: update and new records. Aquatic Invasions, 10(4), 425-438. DOI:10.3391/ai.2015.10.4.06

Jimenez, C., Petrou, A., Andreou, V., Hadjioannou, L., Wolf, W., Koutsoloukas, N. \& Abu Alhaija, R. (2016). Veni, vidi, vici: the successful establishment of the lionfish Pterois miles in Cyprus (Levantine Sea). Commission Internationale pour l'Exploration Scientifique de la Méditerranée, 41, 417.

Jimenez, C., Andreou, V., Hadjioannou, L., Petrou, A., Alhaija, R.A. \& Patsalou, P. (2017). Not everyone's cup of tea: Public perception of culling invasive lionfish in Cyprus Journal of the Black Sea / Mediterranean Environment, 23(1), 38-47.

Johnston, M. W. \& Purkis, S. J. (2011). Spatial analysis of the invasion of lionfish in the western Atlantic and Caribbean. Marine Pollution Bulletin, 62(6), 1218-1226. Marine Pollution Bulletin, 62, 12181226. DOI: 10.1016/j.marpolbul.2011.03.028

Kimball, M., Miller, J., Whitfield, P. \& Hare, J. (2004). Thermal tolerance and potential distribution of invasive lionfish (Pterois volitans/ miles complex) on the east coast of the United States. Marine 
Ecology Progress Series, 283, 269-278. DOI: 10.3354/meps283269

Kletou, D., Hall-Spencer, J.M. \& Kleitou, P. (2016). A lionfish (Pterois miles) invasion has begun in the Mediterranean Sea. Marine Biodiversity Records, 9(1). DOI: 10.1186/s41200-016-0065-y

Meister, H. S., Wyanski, D. M., Loefer, J. K., Ross, S. W., Quattrini, A. M. \& Sulak, K. J. (2005). Further Evidence for the Invasion and Establishment of Pterois volitans (Teleostei: Scorpaenidae) Along the Atlantic Coast of the United States. Southeastern Naturalist, 4(2), 193-206. DOI: 10.1656/1528-7092(2005)00

Morris, J.A. \& Akins, J.L. (2009). Feeding ecology of invasive lionfish (Pterois volitans) in the Bahamian archipelago. Environmental Biology of Fishes, 86(3), 389-398. DOI: $10.1007 / \mathrm{s} 10641-009-9538-8$

Morris, J.A. (2009). The Biology and Ecology of the Invasive IndoPacific Lionfish. PhD thesis, North Carolina State University, Raleigh, NC

Mytilineou, Ch., Akel, E. H. Kh., Babalı, N., Balistreri, P., Bariche, M., .. \& Zenetos, A. (2016). New Mediterranean Biodiversity Records (November, 2016). Meditterranean Marine Science, 17(3), 794-821.

NMFS (2015). National Invasive Lionfish Prevention and Management Plan, National Marine Fisheries Service, Aquatic Nuisance Species Task Force Press Release.

Nuttall, M.F., Johnston, M.A., Eckert, R.J., Embesi, J.A., Hickerson, E.L. \& Schmahl, G. P. (2014). Lionfish (Pterois volitans [Linnaeus, 1758] and $P$. miles [Bennett, 1828]) records within mesophotic depth ranges on natural banks in the Northwestern Gulf of Mexico. Biolnvasions Records, 3, 111-115. DOI: 10.3391/bir.2014.3.2.09

Oray, I.K., Sınay, E., Saadet Karakulak, F. \& Yıldız, T. (2015). An expected marine alien fish caught at the coast of Northern Cyprus: Pterois miles (Bennett, 1828). Journal of Applied Ichthyology, 31(4), 733735. DOI:10.1111/jai.12857

Özgür Özbek, E., Mavruk, S., Saygu, İ. \& Öztürk, B. (2017). Lionfish distribution in the eastern Mediterranean coast of Turkey. Journal of the Black Sea / Mediterranean Environment, 23(1), 1-16.

Poursanidis, D. (2015). Ecological niche modeling of the the invasive lionfish Pterois miles (Bennett, 1828) in the Mediterranean Sea. Proceeding of $11^{\text {th }}$ Panhellenic Symposium on Oceanography and Fisheries, Lesvos Island, Greece.

Quattrini, A.M., Demopoulos, A.W., Singer, R., Roa-Varon, A. \& Chaytor, J.D. (2017). Demersal fish assemblages on seamounts and other rugged features in the northeastern Caribbean. Deep
Sea Research Part I: Oceanographic Research Papers, 123, 90-104. DOI: 10.1016/j.dsr.2017.03.009

Ruttenberg, B. I., Schofield, P. J., Akins, J. L., Acosta, A., Feeley, M. W. Blondeau, J., ... \& Ault, J. S. (2012). Rapid Invasion of Indo-Pacific Lionfishes (Pterois Volitans and Pterois Miles) in the Florida Keys, USA: Evidence from Multiple Pre- and Post-Invasion Data Sets. Bulletin of Marine Science, 88(4), 1051-1059. DOI: $10.5343 / \mathrm{bms} .2011 .1108$

Schofield, P. (2009). Geographic extent and chronology of the invasion of non-native lionfish (Pterois volitans [Linnaeus 1758] and P. miles [Bennett 1828]) in the Western North Atlantic and Caribbean Sea. Aquatic Invasions, 4(3), 473-479. DOI:10.3391/ai.2009.4.3.5

Schofield, P. (2010). Update on geographic spread of invasive lionfishes (Pterois volitans [Linnaeus, 1758] and P. miles [Bennett, 1828]) in the Western North Atlantic Ocean, Caribbean Sea and Gulf of Mexico. Aquatic Invasions, 5(1), 117-122. DOI: 10.3391/ai.2010.5.s1.024

Tornabene, L. \& Baldwin, C.C. (2017). A new mesophotic goby, Palatogobius incendius (Teleostei: Gobiidae), and the first record of invasive lionfish preying on undescribed biodiversity. PLOS ONE, 12(5), e0177179. DOI: 10.1371/journal.pone.0177179

Turan, C., Ergüden, D., Gürlek, M., Yağlığlu, D., Uyan, A. \& Uygur, N. (2014). First record of the Indo-Pacific lionfish Pterois miles (Bennett, 1828) (Osteichthyes: Scorpaenidae) for the Turkish marine waters. Journal of the Black Sea/Mediterranean Environment, 20, 158-163.

Turan, C. \& Öztürk, B. (2015). First record of the lionfish Pterois miles from the Aegean Sea. Journal of the Black Sea/Mediterranean Environment, 21, 334-338.

Turingan, R. \&Sloan,T.(2016).Thermal Resilience ofFeeding Kinematics May Contribute to the Spread of Invasive Fishes in Light of Climate Change. Biology, 5(4), 46. DOI: 10.3390/biology5040046

Yağlıoğlu, D. \& Ayas, D. (2016). New occurrence data of four alien fishes (Pisodonophis semicinctus, Pterois miles, Scarus ghobban and Parupeneus forsskali) from the North Eastern Mediterranean (Yeşilovacık Bay, Turkey). Biharean Biologist, 10(2), 150-152. 